\title{
The past and present occurrence of Elatine and implications for palaeoenvironmental reconstructions
}

\author{
Otto Brinkkemper $\cdot$ Eddy J. Weeda • \\ Sjoerd J. P. Bohncke · Wim J. Kuijper
}

Received: 12 April 2006/Accepted: 14 November 2006/Published online: 19 June 2007

(C) Springer-Verlag 2007

\begin{abstract}
The past and present occurrence of Elatine hydropiper L. (eight-stamened waterwort), E. hexandra (Lapierre) DC. (six-stamened waterwort) and E. triandra Schkuhr (three-stamened waterwort) in the Netherlands is discussed. It has proved possible to distinguish the slightly curved seeds of E. hexandra and E. triandra in subfossil material on morphological grounds. E. hexandra is the most common species at present, but subfossil finds are confined to Late-glacial and Pre-boreal sediments of one lake in the Pleistocene area of the Netherlands. Living plants of E. triandra have only been found in the Netherlands in 1838-1839, but there are 17 records from five archaeological sites, all located in the western Dutch estuarine area. Several of these sites also yielded E. hydropiper, archaeobotanically the most common species. The occurrence of E. triandra and E. hydropiper in the Netherlands seems to have been favoured by high summer temperatures. The ecological amplitude of this combina-
\end{abstract}

O. Brinkkemper $(\bowtie)$

RACM, P.O. Box 1600, 3800 BP Amersfoort, The Netherlands e-mail: o.brinkkemper@racm.nl

E. J. Weeda

Alterra, P.O. Box 47, 6700 AA Wageningen, The Netherlands

e-mail: eddy.weeda@wur.nl

\section{S. J. P. Bohncke}

Instituut voor Aardwetenschappen, De Boelelaan 1085,

1081 HV Amsterdam, The Netherlands

e-mail: sjoerd.bohncke@falw.vu.nl

W. J. Kuijper

Archeologisch Centrum, Postbus 9515, 2300 RA Leiden,

The Netherlands

e-mail: w.j.kuijper@arch.leidenuniv.nl tion of species gives firm clues for the reconstruction of the environment, which must have been a freshwater tidal area. Since this type of environment is strongly threatened on a worldwide scale, the presence of these species in the past may also provide interesting information for present nature development projects in the Dutch estuarine area.

Keywords Archaeobotany - Elatine $\cdot$ Freshwater tidal area $\cdot$ Palaeoecology

\section{Introduction}

In this volume dedicated to Corrie Bakels, we further explore one of the many tracks she set out in her long and fruitful scientific career. We will focus on an environment that has often been visited by Corrie, where she studied sites like Hekelingen, Hazendonk and Hardinxveld-Giessendam (see Bakels 1981, 1988; Bakels et al. 2001; Bakels and Van Beurden 2001). These sites are situated in the estuaries of the central Dutch riverine area, a highly characteristic environment with high and dry river dunes and high biomass production in the estuaries that attracted late Mesolithic and early Neolithic people. Nowadays, this characteristic type of wetland environment is endangered on a worldwide scale (Barendregt et al. 2006).

The reconstruction of the environment of archaeological sites is one of the main issues to be addressed in archaeobotanical research. Where the preservation conditions are favourable, pollen, wood and charcoal as well as seeds, fruits and other botanical macroremains can be used as sources of information to reconstruct the palaeoenvironment. Waterlogging is the most important condition for the preservation of uncarbonised plant remains. The western part of the Netherlands, with the estuaries of the rivers 
Rhine and Maas, forms an extensive area with waterlogged archaeological sites and related deposits. Therefore, this area offers excellent possibilities for studies into the environment in which humans were active in the past.

The present ecology is generally used as a starting point to acquire information about the past environment. Two main directions of research can be distinguished. The first can be called the synecological approach. Specific combinations of plant species form vegetation types that are characteristic of specific habitats. These combinations are called plant communities, and these can be described with character species (German Kennarten) and differentiating species (German Trennarten). This synecological approach to vegetation has been developed by Braun-Blanquet (1928) in the so-called French-Swiss school of vegetation analysis (Westhoff and Van der Maarel 1973). Relevés (German Aufnahmen), or records of plant species growing together in a particular environment, form the building stones for describing these plant communities.

The second direction for reconstructing past environments makes use of ecological characteristics of individual species and is called the autecological approach. It was provided with a scheme which allowed it to be used quantitatively by Ellenberg (1974), who attributed indicator values (German Zeigerwerte) on a nine point scale to central European plant species for the environmental factors light, nitrogen content, moisture and acidity. The indicator values for each factor of all plant species found on an archaeological site can be used to plot eco-diagrams (see Willerding 1971).

Some plant species are so highly characteristic of one particular environment that they can be used even more directly to infer past conditions, more than is possible with either of the two approaches described above. Northwestern European species of the genus Elatine (waterwort) offer such a possibility. In the following, we will discuss how environmental reconstructions may be made using the representatives of this characteristic plant genus.

\section{Waterwort species in the Netherlands during the past two centuries}

The three representatives of Elatine native in the Netherlands and other parts of northwestern Europe are E. triandra Schkuhr (three-stamened waterwort), E. hexandra (Lapierre) DC. (six-stamened waterwort) and E. hydropiper L. (eight-stamened waterwort). A fourth species, $E$. alsinastrum L., reaches its northwestern limit just outside the area under consideration (Meusel et al. 1978, p. 286), but its presence in earlier times should not be excluded, judging by scattered records from various parts of Germany (Haeupler and Schönfelder 1988). Several other species occur still more to the south of Europe (Tutin et al. 1968; Casper and Krausch 1981).

The three northwestern waterwort species have in common that they are small-sized annuals with creeping stems; branches might stand up but only rise few centimetres above the soil (see Fig. 1). In general Elatine species are characteristic of habitats with a fluctuating water level. They may behave both as aquatic and as amphibious plants, being able to complete their life-cycles both in shallow water and in sites that have become exposed (Casper and Krausch 1981). They seem to be specialized in exploiting the superficial eutrophy of sandy water-bottoms with a thin cover of silt mixed with organic detritus (Weeda et al. 1987). Stronger accumulation of silt and detritus, which would choke the small annuals, is counteracted by water movement. Natural Elatine habitats are found in rivers and brooks and at the shores of lakes. Artificial counterparts of such habitats may be offered by ditches and sand pits. Several Elatine species have large distribution areas, especially E. triandra which might be termed a cosmopolitan (Hultén 1971; Meusel et al. 1978, p. 286). Within their distribution areas, however, they tend to be of rare occurrence, both in space and in time. Often their localities lie far apart from each other, and frequently their occurrence at a certain site is of short duration. On the other hand, suitable new sites may be rapidly colonized, even if they are situated far from other stations. Presumably waterfowl are the main vector; at least they are known to transport seeds of E. hydropiper (Kerner von Marilaun and Hansen 1916).

In the Netherlands, E. hydropiper was the first species of the genus to be discovered. From 1834 to 1860 it was repeatedly recorded in the centre of the country, notably near Utrecht and Dordrecht. Then for about 70 years no single find was reported. From 1932 to 1974 it was observed again in five localities, most of them not previously known. Only at one station (in the newly reclaimed Noordoostpolder) it persisted for a longer time. Again a period without finds followed, but since 1998 three new localities have been discovered.

Many older records of E. hydropiper refer to plants found on banks of the lower courses of the rivers, which constitute a highly eutrophic habitat. Vegetation records of three such sites contain Limosella aquatica as one of its companions. The banks used to be exposed to the tidal effect but hardly or not to salt water. From about 1970 onwards the freshwater tidal area has shrunk strongly as a result of damming up the greater part of the south-western estuary. The last find of E. hydropiper in this area dates back as far as 1940, however. River canalisation and bank consolidation may have played their part as well.

Several other records refer to ditches and canals at the fringe of Pleistocene and Holocene deposits, notably at the 
Fig. 1 a Plants of Elatine hydropiper with four valved fruit capsule and characteristic U-shaped seed from Hattem; b detail of fruit with seeds from Hattem (photos O. Brinkkemper)
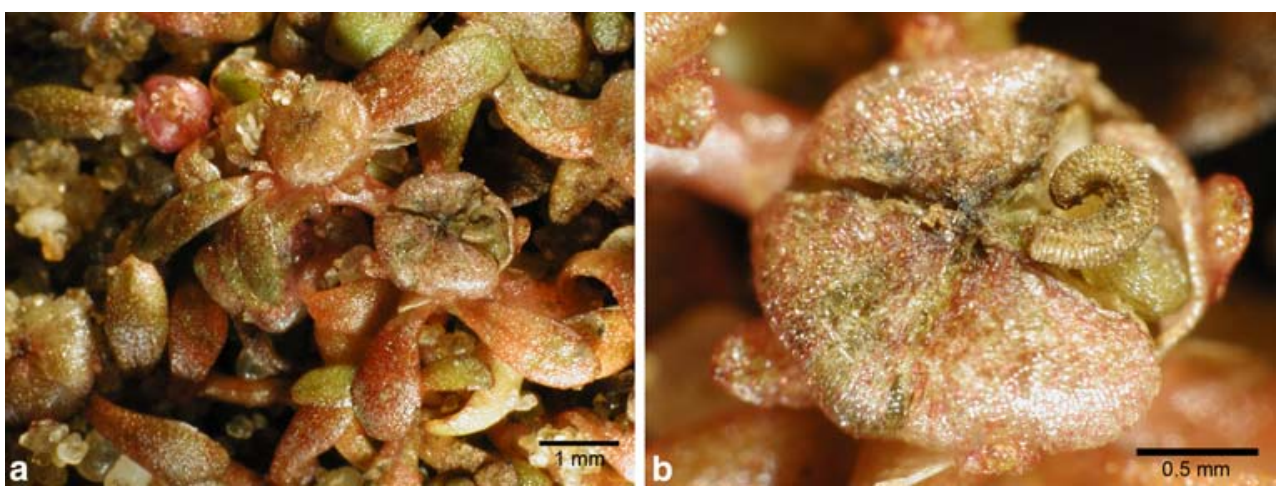

edge of river valleys. There is a notable variation in water trophy. For a brook-like pond near Utrecht, the mesotraphent (growing in mesotrophic conditions) Apium inundatum was mentioned as a companion of E. hydropiper (Hartsen 1865). In more eutrophic ditches it may be accompanied by Ranunculus circinatus, Elodea nuttallii and Potamogeton species (Jager 2000). Two of the three most recent, 21st century finds (Cuijk and Hattem) relate to sand and clay pits which have a narrow connection with a river at one side, causing a fluctuating water table, and are influenced by water from adjacent sandy deposits at the other side. Here again Limosella aquatica is present. All together the phytosociological position of Elatine hydropiper is rather complicated (Jager 2000; Weeda et al. 2003, p. 164). Eleocharis acicularis is the only species that has a considerable overlap with it in various habitats. Almost all specimens of E. hydropiper collected in the Netherlands belong to the aquatic form with waterlogged tissues. Either they grew permanently submerged or they were rinsed daily as a result of tidal water movement. Only in the extremely warm summer of 2003 was a terrestrial form observed (at Hattem, near Zwolle). The specimens in Fig. 1 represent the aquatic form at the Hattem location.

The geographical and ecological pattern of the other two species is less complex. E. triandra has only been recorded in the Netherlands in two subsequent years in the first half of the 19th century, 1838-1839, according to Vuyck (1901); the record for 1859 in Mennema et al. (1980) appears to be spurious. It was almost confined to the freshwater tidal area near Dordrecht, where it co-occurred with E. hydropiper in several stations. In Utrecht one single specimen was observed. All herbarium material represents the aquatic form.

E. hexandra was the last species of the genus to be discovered in the Netherlands, in 1849 in the Uddelermeer in the central Pleistocene sand area called Veluwe. According to a 19th century description by Van Eeden (1880, p. 209) this lake must have been mesotrophic by that time, bearing Nymphaea alba on its surface and amongst others Phragmites australis, Hypericum elodes, Elatine hexandra, Eriophorum angustifolium and Sphagnum along its shores.

Apparently E. hexandra was very rare in the Netherlands up to ca. 1940, records being confined to the Veluwe and one single spot in the south of the country. After that year E. hexandra gradually became more common, spreading over various Pleistocene parts of the Netherlands, notably in the southern province of Noord-Brabant (see Fig. 2). In 2003 it was observed for the first time in the riverine area, at a site near Hattem bordering on the Veluwe sands, together with E. hydropiper. Unlike its relatives, E. hexandra has its main centre of distribution in Atlantic parts of Europe, notably in France (Meusel et al. 1978, p. 286), which suggests a higher warmth demand. It

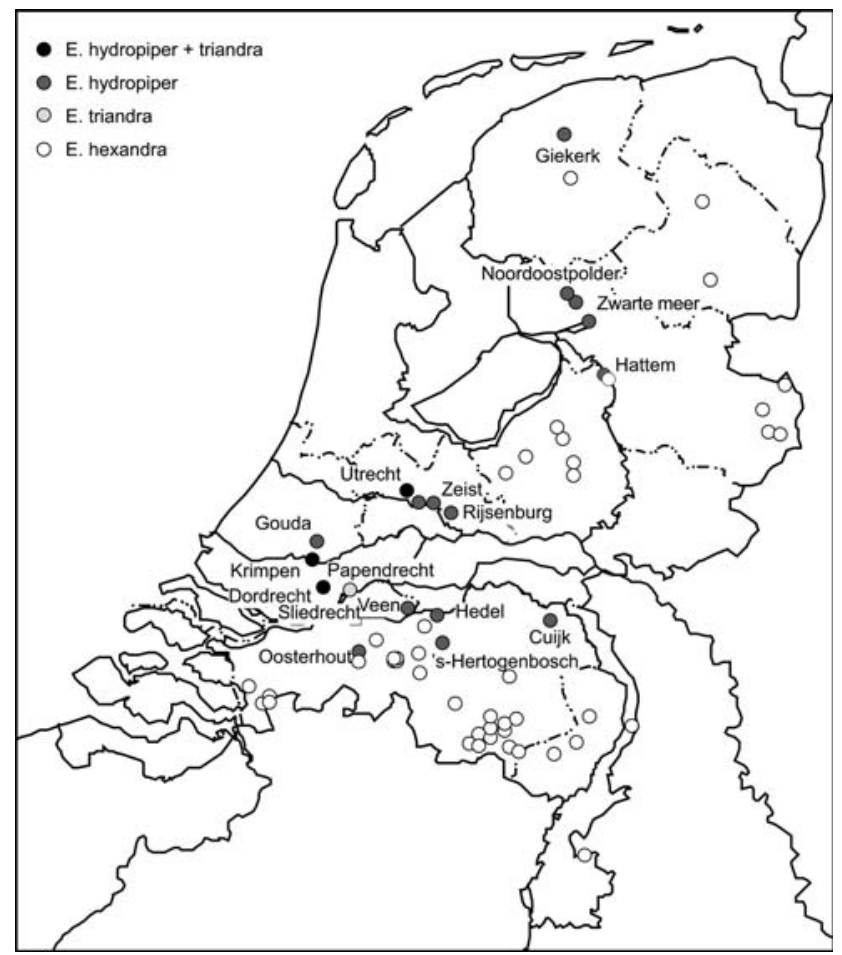

Fig. 2 Distribution map of 19th/20th century find spots of Elatine sp. in the Netherlands 
also grows in a more mesotrophic habitat than E. triandra or E. hydropiper, many stations lying in heathland reserves. Again Eleocharis acicularis is among the most constant companions (Hofstra and Weeda 1977; Schaminée et al. 1995, p. 134; Weeda et al. 2000, p. 202). After 1980 it was clearly favoured by nature restoration measures in heathland pools. In contrast to the other two species, E. hexandra is most often encountered in its terrestrial form and only rarely in its aquatic form. Increasing water table fluctuations in pools, caused by drainage of the surroundings, will therefore foster E. hexandra rather than E. triandra or E. hydropiper.

\section{Subfossil finds of waterwort species}

In archaeobotanical and palaeoecological studies, the characteristically U-shaped seeds of E. hydropiper can easily be identified (see Fig. 3, compare also Fig. 1b). Waterlogged seeds have been found in 38 samples from 14 sites in the Netherlands (see Table 1). These are strikingly high numbers in comparison with the present rarity of this species.

Late Pleistocene and Pre-boreal records from two lakes on Pleistocene sandy soils of the Veluwe occur in lacustrine deposits (gyttja). They come from the Uddelermeer and the nearby Bleekemeer (meer = lake). Curiously enough, the Uddelermeer was a station of $E$. hexandra in the 19th century, as has been stated before. So in this particular case E. hydropiper represents an earlier stage of the lake than E. hexandra, presumably with less acid water and lower water temperatures. From the last two centuries no station of E. hydropiper with a similar geographical context to the Uddelermeer and the Bleekemeer is known from the Netherlands.

All later Holocene records, derived from archaeological contexts, are situated in the Dutch riverine area (see Fig. 4). With the exception of Arnhem, all sites are located in the western part of the Netherlands. They connect to the 19th century finds near Dordrecht and Utrecht, but extend considerably further in the direction of the North Sea coast.
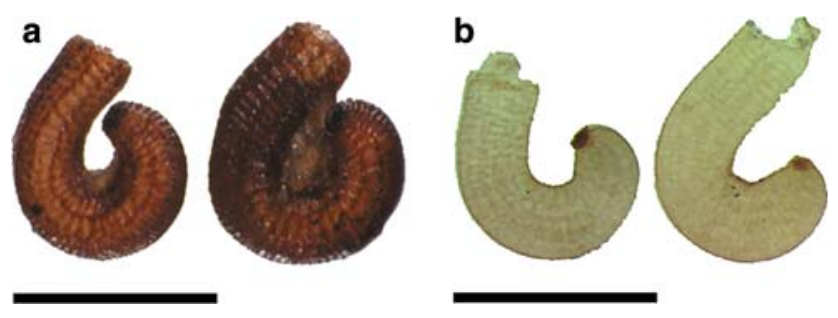

Fig. 3 Subfossil seeds of Elatine hydropiper from a RotterdamRandstadrail and b Uddel-Uddelermeer (photos O. Brinkkemper and S. Bohncke); scale bar $0.5 \mathrm{~mm}$
No doubt most, if not all, sites belonged to the freshwater tidal area. The finds near the present 'Oude Rijn' (Vleuten, Woerden and Valkenburg) date back to the Roman period, when this was the main lower course of the Rhine. For the Arnhem site, tidal influence is not plausible. It borders on the Veluwe and may have had a similar character as the present location near Hattem and Cuijk, a contact belt between Pleistocene sands and a river valley.

Both the other native Elatine species have only slightly curved and weakly J-shaped seeds. They are often considered as indistinguishable and are identified as E. hexandra/triandra. We attempted to find diagnostic features to distinguish seeds of E. hexandra from E. triandra. For this, we studied material from Nederweert (1992), Voorthuizen (1962) and Ossendrecht (1961) from the Dutch State Herbarium in Leiden, as well as our own collected material from Hattem (2004), the Netherlands, for E. hexandra and from Sliedrecht (1938), the Netherlands, and Akersvika (1982), Norway, for E. triandra. We included E. hydropiper in this study, because the 20th edition of the Dutch flora mentions the seeds of this species being 'almost straight to horseshoe-shaped' (Van der Meijden et al. 1983, p. 246, apparently following Tutin et al. 1968). We examined dozens of plants from various Dutch origins, and without exception the seeds were strongly curved (180$330^{\circ}$ relative to the largest straight part).

The characteristics which we examined (see Table 2) proved to be uniform for the different provenances within each species. On the basis of this data, it appears to be possible to distinguish seeds of E. hexandra from those of E. triandra. E. hexandra has seeds wider than $0.2 \mathrm{~mm}$ (in microscope slides, the pressure of the cover glass may result in flattening and widths up to $0.3 \mathrm{~mm}$ ) with a pattern of cells clearly wider than high cells (giving a 'scalariform' or ladder-like appearance; see Fig. 5a). E. triandra has (unflattened) seeds of maximally $0.2 \mathrm{~mm}$ width with a pattern of cells slightly wider than high cells ('honey-comb' appearance, see Fig. 5b).

Anderberg (1994, p. 92 and Plate 117) described and illustrated the seeds of the three northwest European Elatine species and also those of E. alsinastrum and E. orthosperma Düben. The latter two species have seeds that are $0.7-0.9 \mathrm{~mm}$ in length, and are therefore larger than recent $E$. hexandraltriandra seeds and our subfossil material. According to her table, the interspaces of the reticulate cell pattern of E. hexandra are wider, but that is not corroborated by the dimensions she gives in the descriptions. Seeds of $E$. hexandra have more acute bases, while in E. triandra the seed base is more or less obtuse. The width of seeds of E. hexandra is reported to be larger (0.2$0.3 \mathrm{~mm}$ ) than for E. triandra $(0.1-0.2 \mathrm{~mm})$. This corresponds well with the SEM photos provided by her (1994, Plate 117, all B-illustrations). The differences in width agree 
Table 1 Finds of Elatine hydropiper in archaeobotanical and palaeoecological samples from the Netherlands. Dates are given in calibrated calendar years

\begin{tabular}{|c|c|c|c|c|c|}
\hline Site & Begin date & End date & Sample code & Number & Reference \\
\hline Dordrecht-Tolbrug & 1450 & 1600 & DDTB107 & 4 & Pals (1972) \\
\hline Dordrecht-Tolbrug & 1400 & 1500 & DDTB114 & 1 & Pals (1972) \\
\hline Dordrecht-Tolbrug & 1400 & 1500 & DDTB112 & 1 & Pals (1972) \\
\hline Dordrecht-Tolbrug & 1300 & 1400 & DDTB122 & 1 & Pals (1972) \\
\hline Dordrecht-Tolbrug & 1300 & 1400 & DDTB123 & 1 & Pals (1972) \\
\hline Vlaardingen-Gat in de Markt & 1225 & 1275 & Vl-GidM-1095 & 8 & Brinkkemper (2005) \\
\hline Valkenburg-Marktveld & 150 & 250 & VAMA32’539 & 1 & Brinkkemper (unpublished) \\
\hline Papendrechtse Stroomrug & 150 & 200 & PAP-227 & 33 & Stuijts et al. (1999) \\
\hline Papendrechtse Stroomrug & 150 & 200 & PAP-245 & 5 & Stuijts et al. (1999) \\
\hline Valkenburg-Marktveld & 90 & 150 & VAMA45'177 & 1 & Brinkkemper (unpublished) \\
\hline Vleuten-De Meern Veldhuizen & 75 & 100 & Vl-2-3-23 & 8 & Van Haaster and Vermeeren (2001) \\
\hline Woerden-Molenstraat & 50 & 250 & WMK_9038 & 5 & Brinkkemper and De Man (1999) \\
\hline Valkenburg-Marktveld & 25 & 75 & VAMA2a-45’200 & 10 & Noordam and Pals (1987) \\
\hline Geldermalsen-Kalenberg & -500 & -250 & GDM-6/2/31 & 5 & De Man (2002) \\
\hline Streefkerk-de Meerdonk & -4200 & -4000 & MRDK & ca. 20 & Kuijper (unpublished) \\
\hline Brandwijk-Kerkhof & -4030 & -3940 & BRW-pr50-47 & 2 & Kuijper (unpublished) \\
\hline Brandwijk-Kerkhof & -4030 & -3940 & BRW-pr50-32 & 4 & Kuijper (unpublished) \\
\hline Brandwijk-Kerkhof & -4030 & -3940 & BRW-pr50-27 & 17 & Kuijper (unpublished) \\
\hline Brandwijk-Kerkhof & -4030 & -3940 & BRW-pr50-22 & 72 & Kuijper (unpublished) \\
\hline Brandwijk-Kerkhof & -4030 & -3940 & BRW-pr50-17 & 88 & Kuijper (unpublished) \\
\hline Brandwijk-Kerkhof & -4030 & -3940 & BRW-pr50-12 & ca. 400 & Kuijper (unpublished) \\
\hline Brandwijk-Kerkhof & -4030 & -3940 & BRW-pr50-7 & ca. 425 & Kuijper (unpublished) \\
\hline Brandwijk-Kerkhof & -4030 & -3940 & BRW-pr50-1 & 40 & Kuijper (unpublished) \\
\hline Brandwijk-Kerkhof & -4220 & -4100 & BRW-27.7 & ca. 1500 & Kuijper (unpublished) \\
\hline Brandwijk-Kerkhof & -4220 & -4100 & BRW-43.542 & ca. 5700 & Kuijper (unpublished) \\
\hline Brandwijk-Kerkhof & -4220 & -4100 & BRW-13.124 & ca. 2000 & Kuijper (unpublished) \\
\hline Brandwijk-Kerkhof & -4220 & -4100 & BRW-pr50-50 & 2 & Kuijper (unpublished) \\
\hline Hardinxveld-De Bruin & -4700 & -4450 & Bru-294 & 64 & Bakels et al. (2001) \\
\hline Rotterdam-Randstadrail & -5600 & -5400 & Rand-103-15 & 4 & Brinkkemper (2003) \\
\hline Arnhem-Schuytgraaf & -6450 & -4200 & Schuyt-182/520 & 2 & Van Haaster (1998) \\
\hline Arnhem-Schuytgraaf & -6450 & -4200 & Schuyt-90/245 & 2 & Van Haaster (1998) \\
\hline Arnhem-Schuytgraaf & -6450 & -4200 & Schuyt-148/345 & 20 & Van Haaster (1998) \\
\hline Uddel-Bleekemeer & -8500 & -8000 & Late Pre-boreal & 1 & Bohncke and Wijmstra (1988) \\
\hline Uddel-Uddelermeer & -9700 & -8000 & Pre-boreal & 8 & Bohncke and Wijmstra (1988) \\
\hline Uddel-Uddelermeer & -10700 & -9700 & Younger Dryas & 1 & Bohncke and Wijmstra (1988) \\
\hline Uddel-Uddelermeer & -10800 & -10700 & Allerød/Younger Dryas tr. & 4 & Bohncke and Wijmstra (1988) \\
\hline Uddel-Uddelermeer & -11300 & -10800 & Allerød Pinus phase & 5 & Bohncke and Wijmstra (1988) \\
\hline Uddel-Uddelermeer & -13000 & -12000 & Bølling & 3 & Bohncke and Wijmstra (1988) \\
\hline
\end{tabular}

perfectly with our measurements. A consequence of the very narrow width of the seeds of $E$. triandra is that they might pass sieves with meshes of $0.25 \mathrm{~mm}$, generally the smallest mesh size used in archaeobotanical studies. However, all samples yielding these seeds have been processed with this smallest mesh size, so in practice this does allow the detection of these seeds, probably because of the considerably greater length.
On the basis of this data, the subfossil seeds from the western Netherlands can be attributed to E. triandra (because of their relatively small width and their cell pattern), and the Late-glacial to Pre-boreal finds from the Mekelermeer to E. hexandra.

The seeds of E. triandra have been found in 18 samples from six sites (for locations see Fig. 4). All sites are situated in the western part of the Netherlands, and three of 


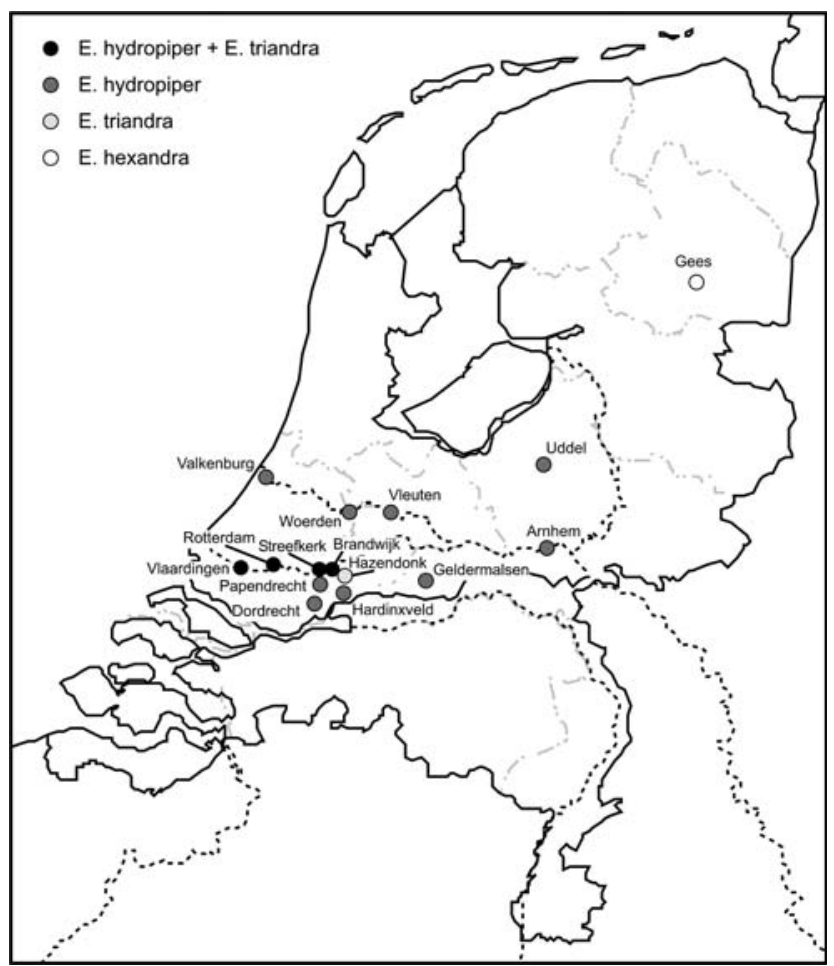

Fig. 4 Distribution map of sites with subfossil finds of Elatine sp. in the Netherlands

these six sites also yielded seeds of $E$. hydropiper. The cooccurrence of E. triandra with E. hydropiper in the freshwater tidal area in the 19th century further substantiates the reliability of the discrimination between E. triandra and E. hexandra.

For one site in Vlaardingen, tidal activity has been attested by archaeological finds. At Vlaardingen-Hoogstad, a system of culverts from the Roman period has been recovered. Several of these culverts are of a type with a valve that allows water flow in only one direction. This system only functions in areas with tidal differences. At low tide, water from the hinterland can be discharged through the culvert as the water pressure opens the valve. At high tide, the water level is above that of the culvert, and the water pressure, now from the other side, closes the
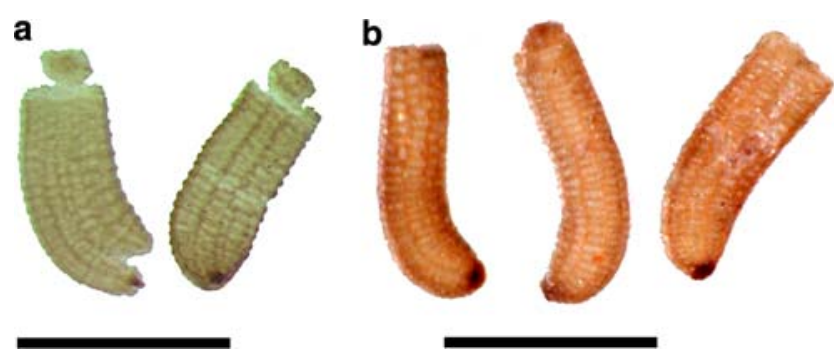

Fig. 5 a Subfossil seed of Elatine hexandra from the Mekelermeer (photo S. Bohncke); b subfossil seed of E. triandra from RotterdamRandstadrail (photo O. Brinkkemper); scale bar $0.5 \mathrm{~mm}$

valve. Inundation of the hinterland is prevented in this way (De Ridder 1999).

Moreover, several of the sites with Elatine remains yielded mollusc shells of Mercuria confusa, a species that is confined to freshwater tidal areas. At present, these animals live in places that become dry during low tide in creeks and along broader rivers in the Netherlands. In the western part of our country, fossil remains of $M$. confusa are only present in the Holocene sediments of the estuaries of the large rivers (Kuijper 2000, 2004). All Dutch finds of E. triandra (see Table 3) are from contexts where gullies are involved. The prehistoric ones are all gullies that border river dunes, which formed Pleistocene outcroppings in the Holocene perifluvial environment.

As to the previous indigenous status of E. triandra in the Netherlands, the archaeological finds show that the finds in 1838-1839 were not accidents. Instead, they document its last 'flourishing' before its complete disappearance.

The only subfossil Dutch find spot of E. hexandra is the Mekelermeer. This is a small lake in a Pleistocene sandy area in the northeastern province of Drenthe, rather similar to the Uddelermeer. In 1952, a single specimen of $E$. hexandra was observed in this same lake (Vegter 1953). Up to now, only one other locality of this species is known in Drenthe (Werkgroep Florakartering Drenthe 1999). Again, the present ecology is in good accordance with the identification to this species. It is more probable that the mesotraphent $E$. hexandra was involved in the Allerød find in the Mekelermeer than the 'tide indicator' E. triandra.
Table 2 Morphological characteristics of seeds of the three Dutch Elatine species

\begin{tabular}{|c|c|c|c|}
\hline & Elatine hexandra & Elatine triandra & Elatine hydropiper \\
\hline Shape & Slightly curved (J) & Slightly curved (J) & Strongly curved (U) \\
\hline Length (mm) & $0.5-0.6$ & $0.45-0.65$ & $0.5-0.6$ \\
\hline Width (mm) & $0.2-0.25$ & $0.15-0.2$ & 0.2 \\
\hline Cell rows & $9-10$ & ca. 10 & ca. 8 \\
\hline Cell width $(\mu \mathrm{m})$ & $50(40-70)$ & $(30-) 50$ & $50-55$ \\
\hline Cell form & $\begin{array}{l}\text { Clearly wider than } \\
\text { high (scalariform) }\end{array}$ & $\begin{array}{l}\text { Slightly wider than high } \\
\text { (honey-comb shaped) }\end{array}$ & $\begin{array}{l}\text { Slightly wider than high } \\
\text { (honey-comb shaped) }\end{array}$ \\
\hline
\end{tabular}


Table 3 Finds of Elatine hexandra and E. triandra in archaeobotanical and palaeoecological samples from the Netherlands. Dates are given in calibrated calendar years

\begin{tabular}{|c|c|c|c|c|c|}
\hline Site name & Begin date & End date & Sample code & Number & Reference \\
\hline \multicolumn{6}{|l|}{ Elatine triandra } \\
\hline Vlaardingen-Schravendijkplein & 1150 & 1325 & VLSP-90 & 8 & Brinkkemper and De Ridder (2003) \\
\hline Vlaardingen-Hoogstad 5.19 & 150 & 175 & V15_19-444 & 8 & Brinkkemper and De Ridder (2001) \\
\hline Brandwijk-Kerkhof & -4030 & -3940 & BRW-pr50-32 & 4 & Kuijper (unpublished) \\
\hline Brandwijk-Kerkhof & -4030 & -3940 & BRW-pr50-27 & 4 & Kuijper (unpublished) \\
\hline Brandwijk-Kerkhof & -4030 & -3940 & BRW-pr50-22 & 8 & Kuijper (unpublished) \\
\hline Brandwijk-Kerkhof & -4030 & -3940 & BRW-pr50-17 & 4 & Kuijper (unpublished) \\
\hline Brandwijk-Kerkhof & -4030 & -3940 & BRW-pr50-7 & 9 & Kuijper (unpublished) \\
\hline Brandwijk-Kerkhof & -4220 & -4100 & BRW-27.7 & ca. 200 & Kuijper (unpublished) \\
\hline Brandwijk-Kerkhof & -4220 & -4100 & BRW-43.542 & ca. 750 & Kuijper (unpublished) \\
\hline Streefkerk-de Meerdonk & -4200 & -4000 & MRDK & ca. 3 & Kuijper (unpublished) \\
\hline Molenaarsgraaf-Hazendonk & -4020 & -3960 & Haz-B3-94 & 5 & Kuijper (unpublished) \\
\hline Molenaarsgraaf-Hazendonk & -4020 & -3960 & Haz-B3-89 & 2 & Kuijper (unpublished) \\
\hline Molenaarsgraaf-Hazendonk & -4020 & -3960 & Haz-B3-83 & 1 & Kuijper (unpublished) \\
\hline Molenaarsgraaf-Hazendonk & -4500 & -4300 & Haz-B3-6 & 1 & Kuijper (unpublished) \\
\hline Rotterdam-Randstadrail & -5600 & -5400 & Rand-107-2 & 4 & Brinkkemper (2003) \\
\hline Rotterdam-Randstadrail & -5600 & -5400 & Rand-107-1 & 84 & Brinkkemper (2003) \\
\hline Rotterdam-Randstadrail & -5600 & -5400 & Rand-103-15 & 10 & Brinkkemper (2003) \\
\hline Rotterdam-Randstadrail & -5600 & -5400 & Rand-103-13 & 2 & Brinkkemper (2003) \\
\hline \multicolumn{6}{|l|}{ Elatine hexandra } \\
\hline Gees-Mekelermeer & -11300 & -10800 & Allerød Pinus phase & 1 & Bohncke and Wijmstra (1988) \\
\hline Gees-Mekelermeer & -11800 & -11300 & Allerød Betula phase & 1 & Bohncke and Wijmstra (1988) \\
\hline
\end{tabular}

The history of 19th and 20th century finds of E. hexandra suggests a rather recent appearance followed by a gradual increase, whilst the Mekelermeer record from the Allerød points to a much longer history.

Apart from the finds of seeds, some pollen of Elatine has been identified as well. Nine grains from four different spectra from the Hazendonk have been identified tentatively by A. Louwe Kooijmans (unpublished data, W.A. Out, personal communication). These records show hardly any correlation with the layers containing Elatine seeds from the same site. Some ca. 18th century sediments of the Uddelermeer also yielded Elatine pollen (unpublished data, S. Bohncke).

\section{The occurrence of Elatine in relation to climatic conditions}

The sudden increase in the number of find spots of $E$. hydropiper in the Netherlands leads to the question as to how this increase might be explained. The exceptionally warm summers at the start of the 21 st century triggered the idea of a possible relation to climatic conditions. To further explore this idea, the subfossil finds of both E. hydropiper and E. triandra were plotted on a time scale by using the average between begin and end date of the samples concerned, rounded off to hundreds of years. The number of samples with presence of either species (not the numbers of seeds) were then plotted in Fig. 6 together with the normalized Polar Circulation Index (PCI) from the GISP2 icecore (Mayewski et al. 1997, as published by Magny 2004). Negative values of this index indicate warm temperatures. The comparison of both graphs shows that the large number of finds from the fourth millennium B.C. correspond to the warmer Atlantic period temperatures. The finds in the fifth millennium B.C. seem to be less clearly related to higher temperatures, but the records from Arnhem-Schuytgraaf, plotted at 5300 B.C. have a wide dating range that extends from 6450 up to 4200 B.C. These finds of $E$. hydropiper could therefore also fall in the group of records from the fourth millennium.

The records around the start of our era again correspond to more negative PCI values and thus with warmer temperatures. The occurrence of Elatine in the second millennium A.D. generally fall before the start of the Little Ice Age in the 16th century. Only one relatively widely dated sample of A.D. 1450-1600 from Dordrecht might correspond with the start of this cold period. 
Fig. 6 The sample frequency of seeds of Elatine hydropiper and E. triandra (bars) and the normalised polar circulation index (PCI) from the Greenland GISP2 ice core. The dotted line represents the total number of investigated samples in the Dutch coastal and river districts $(\log \mathrm{N}+1$-scale $)$

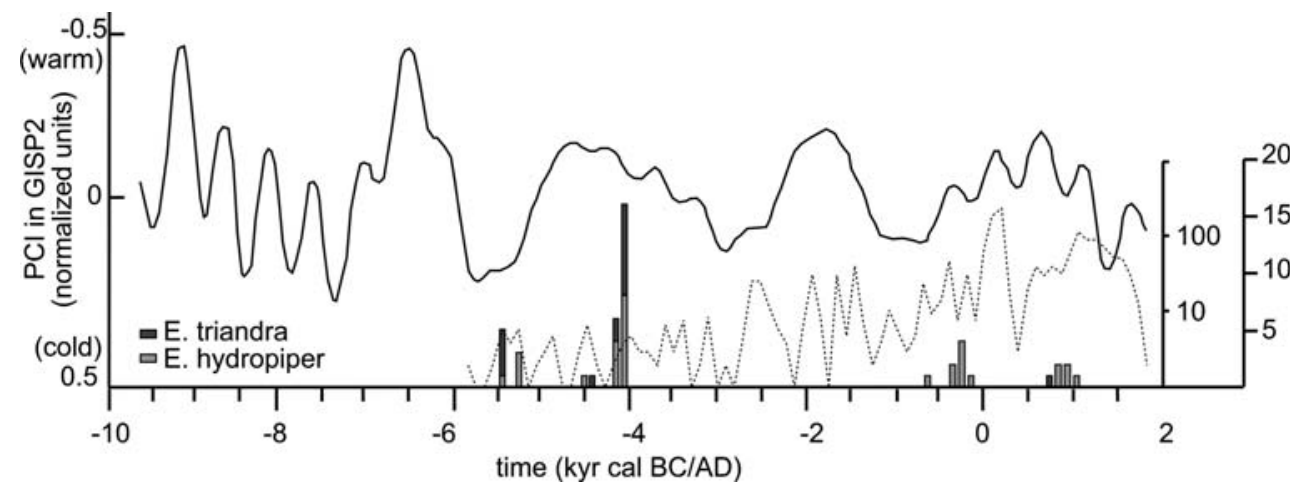

The total number of samples per century in the Dutch archaeobotanical database RADAR was also assessed for all coastal and riverine archaeological regions. These numbers are shown by the dotted line in Fig. 6. This line clearly illustrates that the absence of Elatine finds in colder phases cannot be attributed to a lack of samples studied.

The restriction of subfossil finds of E. hexandra to Lateglacial sediments and the lack of Holocene records do not permit a well-founded discussion of the relationship of this species to climatic conditions. It neither shows the sudden recent increase of E. hydropiper, but instead has been found regularly throughout the last and present century.

It would be interesting to explore further the relation between E. hydropiper and E. triandra and climate in the future with a larger data set of records of both Elatine species.

\section{Subfossil finds of Elatine seeds in northwestern Europe}

Archaeobotanical records of Elatine species elsewhere in northwestern Europe are very scarce. Knörzer (1996, p. 101) reported E. hydropiper from a ninth century A.D. deposit of drift litter along the river Rhine as the first find of this species in the lower Rhine area. Knörzer and Meurers-Balke (2002, p. 144) published seeds identified as E. hexandra from an Iron Age (La Tène) site in Porz-Lind (noting that this is the first find of this genus in the lower Rhine area, which does not agree with the find mentioned above). They do not consider E. triandra, probably because their site is outside the supposed distribution area of this species.

The British database for archaeobotanical remains contains three records, all of E. hydropiper. Two are from estuarine areas (Graveney boat; tenth century A.D., and Brigg Raft; undated, see Wilson and Conolly 1978; Hillman 1981), a third record is from four samples from channel-fill deposits at Southwark, the oldest possibly Roman, the youngest certainly late to post-medieval (Tyers 1988).
Elatine seeds are already known much further back in time, from Miocene deposits (5.3-23 Ma; Mai and Walther 1988). These authors also mention E. pseudoalsinastrum from the Pliocene (2.6-5.3 Ma) in Germany. The oldest Dutch finds of $E$. hydropiper are from Tegelen in the province of Limburg (Verkuil 1981; Langeveld 2005). They date from the first Pleistocene Interglacial, the Tiglian (1.8-2.4 Ma).

From the Middle Pleistocene, we know some German finds. E. alsinastrum has been recorded from the Kärlicher Interglacial (385-425 Ka) at the Kärlich type site (Bittmann 1992, 1995). E. hydropiper has been found in several Holstein Interglacial (300-335 Ka) deposits (Kempf 1966).

Against the background of its present rarity, the relatively large number of Holocene records of E. hydropiper and, to a lesser extent, E. triandra from the Netherlands demands an explanation. Whilst the western part of the country had the character of a river delta, the freshwater tidal area must have been quite extensive and would have offered excellent habitats for both Elatine species, provided that the climatic conditions were favourable. The more this delta was controlled (by construction of dykes), the less room remained for E. hydropiper and E. triandra. Lately the rivers have been cautiously freed from control here and there, and the former species has already started to benefit from the new opportunities.

Because of their remarkably narrow ecological requirements, the presence of E. hydropiper and/or E. triandra offers the archaeobotanist clear information about the presence of freshwater tidal areas in the past, which is crucial for the reconstruction of former environments inhabited by people, and which brings us back to one of the focal points of research of Corrie Bakels, to whom this volume of Vegetation History and Archaeobotany is devoted. On the other hand, the past occurrence of these species also provides interesting points of view for the present natural development projects carried out in estuarine areas.

Acknowledgments This contribution is dedicated to Prof. Dr. Corrie Bakels on the occasion of her 65th birthday. With this article, 
the first author expresses his gratitude to her for introducing him in the fascinating world of wetland archaeobotany. The authors wish to express their gratitude towards Dr. Allan Hall (University of York) for British archaeobotanical references of Elatine and to Dr. Felix Bittmann (Niedersächsisches Institut für historische Küstenforschung) for German references. Dr. Laura Kooistra (BIAX Consult, Zaandam) and Dr. Allan Hall gave valuable comments on earlier versions of this article.

\section{References}

Anderberg A-L (1994) Atlas of seeds, part 4. Swedish Museum of Natural History, Stockholm

Bakels CC (1981) Neolithic plant remains from the Hazendonk, prov. of Zuid-Holland, the Netherlands. Zeitschr Archäol 15:141-148

Bakels CC (1988) Hekelingen, a neolithic site in the swamps of the Meuse estuary. In: Küster H (ed) Der prähistorische Mensch und seine Umwelt. Festschrift U. Körber-Grohne. Forschungen und Berichte zur Vor- und Frühgeschichte in Baden-Württemberg 31:155-161

Bakels CC, van Beurden LM (2001) Archeobotanie. In: Louwe Kooijmans LP (ed) Archeologie in de Betuweroute. Hardinxveld-Giessendam Polderweg. Een Mesolithisch jachtkamp in het rivierengebied (5500-5000 v. Chr.) [A Mesolithic hunting camp in the river area (5500-5000 B.C.)]. Rapportage Archeologische Monumentenzorg 83, pp 325-378

Bakels CC, van Beurden LM, Vernimmen TJJ (2001) Archeobotanie. In: Louwe Kooijmans LP (ed) Archeologie in de Betuweroute. Hardinxveld-Giessendam De Bruin. Een kampplaats uit het Laat-Mesolithicum en het begin van de Swifterbant-cultuur (5500-4450 v.Chr.) [A camp site from the Late Mesolithic and the start of the Swifterbant culture (5500-4450 B.C.)]. Rapportage Archeologische Monumentenzorg 88, pp 369-433

Barendregt A, Whigham D, Meire P, Baldwin A, van Damme S (2006) Wetlands in the tidal freshwater zone. In: Bobbink R, Beltman B, Verhoeven JTA, Whigham DF (eds) Wetlands: functioning, biodiversity conservation, and restoration. ecological studies 191, Springer, Berlin pp 117-148

Bittmann F (1992) The Kärlich Interglacial, Middle Rhine region, Germany: vegetation history and stratigraphic position. Veget Hist Archaeobot 1:243-258

Bittmann F (1995) Vegetationsgeschichtliche Untersuchungen am Mittel- und Jungpleistozänen Ablagerungen des Neuwieder Beckens (Mittelrhein). Jb RGZM Mainz 38:83-190

Bohncke S, Wijmstra L (1988) Reconstruction of Late-Glacial lakelevel fluctuations in The Netherlands based on palaeobotanical analyses, geochemical results and pollen-density data. Boreas $17: 403-425$

Braun-Blanquet J (1928) Pflanzensoziologie. Grundzüge der Vegetationskunde. Springer, Berlin

Brinkkemper O (2003) Rotterdam-Randstadrail. Botanische resten van een laatmesolithische vindplaats uit het centrum van Rotterdam [Botanical remains from a Late Mesolithic site from the centre of Rotterdam]. Internal report

Brinkkemper O (2005) Vlaardingen-Gat in de Markt. Landschap en voeding van de 10e tot de 13e eeuw [Landscape and food from the 10th to the 13th century]. Internal report

Brinkkemper O, de Man R ( 1999) Archeobotanisch onderzoek. In: Haalebos JK, Vos W (eds) Aanvullend Archeologisch Onderzoek in Woerden [Additional archaeological investigations in Woerden], ADC-rapport 5, pp 27-31

Brinkkemper O, de Ridder T (2001) Archeobotanisch onderzoek naar het milieu rond een nederzetting en een dam uit de Romeinse Tijd (150-175 na Chr.) [Archaeobotanical research into the environment around a settlement and a dam from the Roman Period (150-175 A.D.)]. VLAK-verslag 2.3

Brinkkemper O, de Ridder T (2003) Vlaardingen-Schravendijkplein 1.090. Het archeobotanisch onderzoek [The archaeobotanical research]. VLAK-verslag 5.3

Casper SJ, Krausch H-D (1981) Sü $\beta$ wasserflora von Mitteleuropa, Pteridophyta und Anthophyta, 2. Teil. Spektrum, Stuttgart, New York

De Man R (2002) Archeobotanisch onderzoek aan een afzetting in een geul uit de Midden-IJzertijd te Geldermalsen-Kalenberg [Archaeobotanical research of a sediment in a Middle Iron Age gully at Geldermalsen-Kalenberg]. Interne Rapporten Archeobotanie ROB 2002/1

De Ridder T (1999) De oudste deltawerken van West-Europa. Tweeduizend jaar oude dammen en duikers in Vlaardingen [The eldest deltaworks from Western Europe. Two thousand year old dams and culverts in Vlaardingen]. Tijdschrift voor Waterstaatsgeschiedenis 8:10-22

Ellenberg H (1974) Zeigerwerte der Gefäßpflanzen Mitteleuropas. Scripta Geobotanica 9

Haeupler H, Schönfelder P (1988) Atlas der Farn- und Blütenpflanzen der Bundesrepublik Deutschland, Ulmer, Stuttgart

Hartsen FA (1865) Eene botanische wandeling in de omstreken van Rijsenburg. Proeve eener topographische plantkunde [A botanical trip in the surroundings of Rijsenburg. Trial of a topographical botany]. Album der Natuur 1865:289-304

Hillman G (1981) Macroscopic remains of an estuarine flora. In: McGrail S (ed) Brigg raft. British archaeological reports, British series 89:147-152

Hofstra JJ, Weeda EJ (1977) Over de vegetatie met Elatine hexandra (Lapierre) DC in de kleine plas van het Lonnekermeer [About the vegetation with Elatine hexandra (Lappierre) DC in the small lake of the Lonnekermeer]. Gorteria 8:193-206

Hultén E (1971) The circumpolar plants. II. Dicotyledons. Kungl. Svenska Vetenskapsakademiens Handlingar, 4e ser., 13

Jager HJ (2000) Elatine hydropiper L. (Klein glaskroos) in Nederland teruggevonden [Elatine hydropiper L. (small waterwort) retrieved in the Netherlands]. Gorteria 26:227-229

Kempf EK (1966) Das Holstein-Interglazial von Tönisberg im Rahmen des niederrheinischen Pleistozäns. Eiszeitalter und Gegenwart 17:5-60

Kerner von Marilaun A, Hansen A (1916) Pflanzenleben, vol. 3 Die Pflanzenarten als Floren und Genossenschaften (Abstammungslehre und Pflanzengeographie), 3rd edn. Verlag des bibliographischen Instituts, Leipzig

Knörzer K-H (1996) Pflanzentransport im Rhein zur Römerzeit, im Mittelalter und heute. Decheniana 149:81-123

Knörzer K-H, Meurers-Balke J (2002) Archäobotanische Untersuchungen zur Latène-Siedlung von Porz-Lind. Rheinische Ausgrabungen 47:93-196

Kuijper WJ (2000) De weekdieren van de Nederlandse brakwatergebieden (Mollusca) [The molluscs of the Dutch brackish water areas]. Nederlandse Faunistische Mededelingen 12:41-120

Kuijper WJ (2004) Levensgemeenschappen van mollusken in de overgangsgebieden tussen zoet en zout [Communities of molluscs from the transition between fresh and salt areas]. De Levende Natuur 105:168-169

Langeveld M (2005) Maalbeek in het Tiglien. Botanische macroresten [Maalbeek in the Tiglian. Botanical macroremains]. Bachelor report Leiden University

Magny M (2004) Holocene climate variability as reflected by midEuropean lake-level fluctuations and its probable impact on prehistoric human settlements. Quat Int 113:65-79

Mai DH, Walther H (1988) Die pliozänen Floren von Thüringen, Deutsche Demokratische Republik. Quartärpaläontologie 7:55297 
Mayewski PA, Meeker LD, Twickler MS, Whitlow S, Yang Q, Prentice M (1997) Major features and forcing of high latitude northern hemispheric atmospheric circulation using a 110 000 year long glaciochemical series. J Geophys Res 102:26345-26366

Mennema J, Quené-Boterenbrood AJ, Plate CL (1980) Atlas van de Nederlandse Flora, deel 1: Uitgestorven en zeer zeldzame planten [Atlas of the Dutch flora, part 1: Extinct and very rare plants]. Kosmos, Amsterdam

Meusel H, Jäger EJ, Rauschert S, Weinert E (1978) Vergleichende Chorologie der zentraleuropäischen Flora-Karten-Band II. Gustav Fischer, Jena

Noordam A, Pals JP (1987) In de put zitten ...(2). Zaden uit Valkenburgse waterputten [To be in the depths...(2) Seeds from wells in Valkenburg]. In: Bult EJ, Hallewas DP (eds) Graven bij Valkenburg II [Excavating near Valkenburg II]. Eburon, Delft, pp 56-67

Pals JP (1972) Zadenanalyse stadskernonderzoek Dordrecht [Seed analysis city centre investigations Dordrecht], unpublished manuscript

Schaminée JHJ, Weeda EJ, Westhoff V (1995) De vegetatie van Nederland. Deel 2: Plantengemeenschappen van wateren, moerassen en natte heiden [The vegetation of the Netherlands. Part 2: plant communities of water, marshes and wet heathlands]. Opulus press, Leiden/Uppsala

Stuijts I, Kooistra LI, Hänninen K (1999) Archeobotanie. In: Dijkstra Y, Brinkkemper O, Koot CW (eds) Archeologie in de Betuweroute. Papendrechtse Stroomrug. Rapportage Archeologische Monumentenzorg 80, pp 93-115

Tutin TG, Heywood VH, Burges NA, Moore DM, Valentine DH, Walters SM, Webb DA (eds) (1968) Flora Europaea, Rosaceae to Umbelliferae, vol. 2. Cambridge University Press, Cambridge

Tyers I (1988) Environmental evidence from Southwark and Lambeth. In: Hinton P (ed) Excavations in Southwark and Lambeth 1973-76. Archaeol Soc and Surrey Archaeol Soc Joint Publication 3, pp 443-477

Van der Meijden R, Weeda EJ, Adema FACB, Joncheere GJ de (1983) Flora van Nederland, 20th edn. Wolters-Noordhoff, Groningen

Van Eeden FW (1880) Herinneringen aan de Veluwe (Rememberings of the Veluwe). Album der Natuur 1880: 161-176 and 193-214. Reprint in: Eeden FW van (1886) Onkruid. Botanische wandelingen. De Noordzee-eilanden, Gelderland, Overijssel [Weed.
Botanical walks. The North Sea isles, Guelre, Overijssel]. Schuyt, Haarlem, pp 101-162]

Van Haaster H (1998) Palaeo-ecologisch onderzoek aan enkele grondmonsters van vindplaats 10 in het plangebied 'Schuytgraaf' (gem. Arnhem) [Palaeoecological investigations of some soil samples from site 10 in development-area 'Schuytgraaf' (municipality of Arnhem)]. Internal report BIAX Consult

Van Haaster H, Vermeeren C (2001) Vleuten-De Meern Veldhuizen. Internal report BIAX Consult

Vegter K (1953) Meer Watermontia in Drente (More Montia aquatica in Drenthe). De Levende Natuur 56:100

Verkuil J (1981) De pleistocene flora van Tegelen. Zaden en vruchten [The Pleistocene flora from Tegelen. Seeds and fruits]. Doctoraalscriptie Leiden/Rijksmuseum voor Geologie en Mineralogie

Vuyck L (1901) Prodromus Florae Batavae, edn 2, vol I(1). F. E. MacDonald, Nijmegen

Weeda EJ, Westra R, Westra C, Westra T (1987) Nederlandse Oecologische Flora. Wilde planten en hun relaties 2 [Dutch ecological flora. Wild plants and their relations 2]. IVN, Amsterdam

Weeda EJ, Schaminée JHJ, van Duuren L (2000) Atlas van plantengemeenschappen in Nederland, deel 1. Wateren, moerassen en natte heiden [Atlas of plant communities in the Netherlands, part 1. Water, marshes and wet heathlands]. KNNV uitgeverij, Utrecht

Weeda EJ, Schaminée JHJ, van Duuren L (2003) Atlas van plantengemeenschappen in Nederland, deel 3. Kust en binnenlandse pioniermilieus [Atlas of plant communities in the Netherlands, part 3. Coast and inland pioneer environments]. KNNV uitgeverij, Utrecht

Werkgroep Florakartering Drenthe (1999) Atlas van de Drentse Flora. Schuyt, Haarlem

Westhoff V, van der Maarel E (1973) The Braun-Blanquet approach. In: Whittaker RH (ed) Ordination and classification of vegetation. Junk, The Hague, pp 617-726

Willerding U (1971) Methodische Probleme bei der Untersuchung und Auswertung von Pflanzenfunden in vor- und frühgeschichtlichen Siedlungen. Nachr Nieders Urgesch 40:180-198

Wilson DG, Conolly AP (1978) Plant remains including the evidence for hops. In: Fenwick V (ed) The Graveney Boat: a tenth century find from Kent. British Archaeological Reports, British Series 53, pp 133-150 